日本陌床麻酔学会第27 回大会パネルディスカッション

産科麻酔スタンダードおよび産科との接点

硬膜外麻酔分婏の注意点・開業医の場合

島岡昌幸*

\begin{abstract}
[要旨] 10 年前より硬膜外麻酔分婏を始め約 3,000 例を経験した. 産科周産期医療 者は取り扱うすべての分婏が「分婏時間も非常に短く, その出発点も途中経過もまっ たくスムーズで, 産婦もほとんど気にしないくらいの苦痛ですみ, 新生児も元気で, 後出血も少なく, 産後の回復も順調な分娩(理想型分婏)」でありたいと願っている. 開業以来 22 年間内測法による分婏監視と管理を行ってきた今日, 硬膜外麻酔分婏は 理想型分娩の創出に最良の選択肢の一つであると同時に，「分娩は究極の育児の原点」 であり, 硬膜外麻酔分婏は, 特に母子関係においてこの原点を健やかに育むと確信す るに至った，硬膜外麻酔分婏の実施にあたり，開業医ならではの注意点を述べる． キーワード : 硬膜外麻酔分娩, 無痛分婏, 分娩監視, 選択的誘発麻酔分娩, 理想型分 婏の創出
\end{abstract}

（日臨麻会誌Vol.28 No.5, $765 ７ 77,2008$ )

\section{はじめに}

産科周産期を取り扱う医院を開業して 24 年になる. 近頃の産科周産期の周辺では衰えることのない少子 化傾向に加えて，産婦人科医不足，分娩取扱い施設 の減少等が社会問題となっている.

そのような状況下でも，2006年の日本の分婏の 46\%を診療所，つまり開業医が取り扱つている.

一方，残念なことに，ここ数年，出産体験者から 「お産はもうこりごり」と言われるような疲弊しき った分娩談や，それゆえとも思われる正期産成熟児 の新生児仮死が増えてきた話などを聞く。

すべての産科周産期医療者は分娩後に「こんなお 産だったら，また，産みに来ます」と産婦に言って
もらえることを心より願っている。筆者は 10 年ほ ぞ前，硬膜外麻酔分婏はそう言つてもらえるための 優れた分娩方法であると実感する症例を何例も経験 し，10年後の現在，絶対的にマンパワーに劣る開業 医にとっても硬膜外麻酔による分婏の監視と管理 は，よりょいお産のため, より安全かつ安心で快適 で満足のいくお産のため, きわめて有効な分婏方法 であると確信するに至っている。

産婦人科医だけではなく助産師も少ない。こと に，産婦人科診療所での勤務を希望する助産師はき わめて少ない，加えて産婦人科診療所を希望する看 護師も同じくきわめて少ない，助産師がいない，看 護師がいないためにやむなく分娩取扱いを中止する 診療所もある。助産師不足, 看護師不足は当院もそ
著者連絡先 島岡昌幸

T601-8469 京都市南区唐橋平垣町68 島岡医院 
の例外ではない. 当院では幸い複数の産婦人科医が 予定手術はもちろんのこと, ごくまれに起こる緊急 手術の場合でも即かけつけて親身に指導し援助して くれるが，通常産婦人科医 1 人である。マンパワー に劣る産婦人科診療所が「こんなお産だったら，ま た，産みに来ます」と言ってもらえるようなお産の ための分婏方法の一つに硬膜外麻酔分婏を取り入れ 10 年を経た現在，日本臨床麻酔学会の会員諸兄に一 介の開業産婦人科医が行っている硬膜外麻酔分娩の 実際を，主に妊婦に理解してもらえるよう努めてい る以下の $2 つ の$ 項目,

1. 日本独特 (と思われる)の産科診療所の役割

2. 硬膜外麻酔分娩を始めた理由 に加えて,

3. 硬膜外麻酔分娩の実施にあたり留意している点 をありのままに述べることで，何かのお役に立てれ ばと願っている。

\section{I 日本独特(と思われる)の産婦人科診療所の役割}

産科周産期医療者の任務は，それが開業医であろ うとなかろうとヒトの生命を原点から守ることにあ ることは自明の理である. 加えて, 開業医ならでは の使命もある。それは正期産成熟児の身体と心が歪 みなく成長してくれるよう母子のサポートを行うこ とである。

当院では母乳哺育や新生児期からのスキンケア等 の必然を, 出生前はChild Birth Class (母親教室)で, 出生後は入院中の毎日の診察で, 退院後は 2 歳まで の乳幼児健診に加えて月・木曜日の午後 1 時から 2 時間，「おつぱい村」(写真1) と呼んでいる母子が集 い群れる場において伝えている。

それらの一連のケアを通じて私達は 1 歳までのサ ポートがとても重要な意味をもつことを肌で感じ, 可能なら 2 歳までの母子をサポートする環境の大切 さを感じているが，データとして証明することはで きない。つまり妊娠・出産・子育ての過程が安全か つ健康で快適で，そして納得できるものであるょう

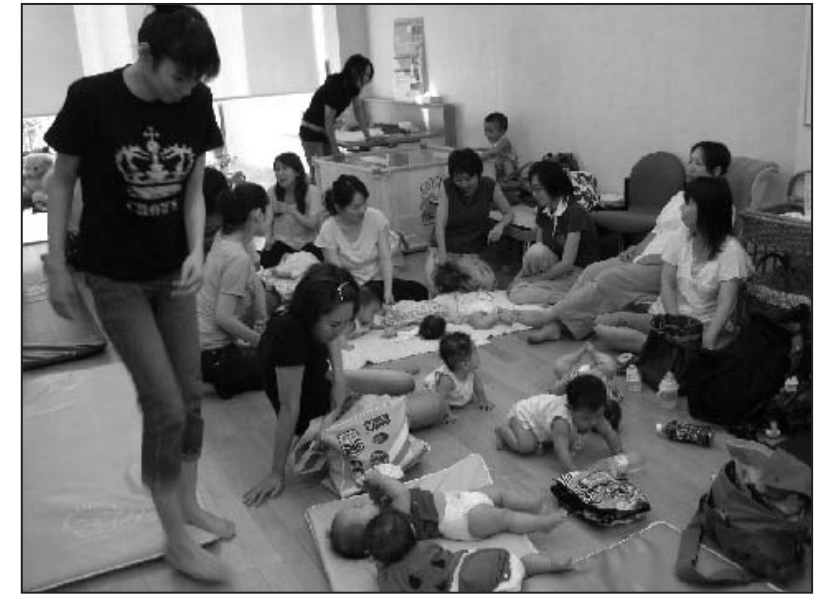

写真1 おっぱい村

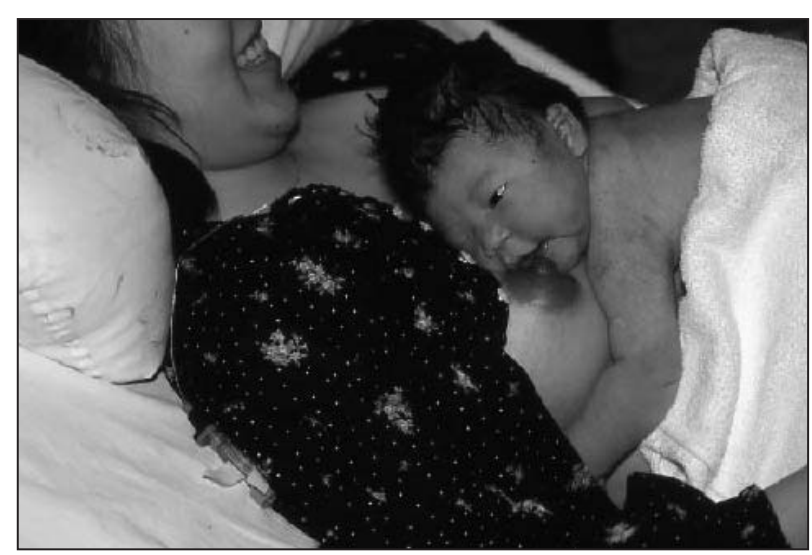

写真2 出生直後のカンガルーケア

サポートするのが産婦人科診療所の役割であると考 えている.

子育ての究極の目的は「やさしい心」をもつ子ど もに育てることであり，この過程を常に同じ医師と スタッフがかかわりをもつことが産婦人科診療所の 最大の特徴と利点である。当然それが欠点になる場 合もある。

妊婦が妊娠中から妊娠は疾病ではないが非妊時と は生理学的に大きく逸脱した状態(病態といっても いい)にあることを知り，胎児は出生直後に血流の 大転換をはじめ驚くべき胎内環境からの変化をもた らす素晴らしい能力があることを知り, 分婏のメカ ニズムと出産後になすべきことを理解し納得してお 


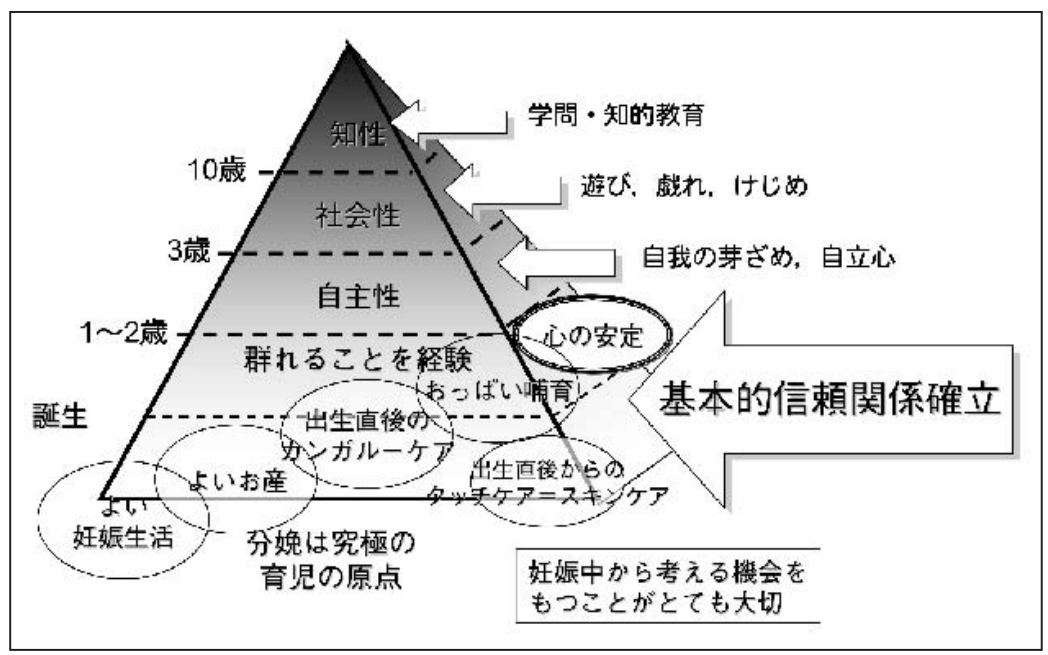

図1 やさしい心が育つ過程

〔発達心理学者エリクソン，小児科橋本武夫より。

(文献1),2)より引用・改変) ]

くことがその基本となる.

よい妊娠生活, よいお産, 出生直後からの母子愛 着(カンガルーケア, 写真2)が, 順調なおつぱい哺 育(母乳栄養ではない)をもたらす。人間の子どもに やさしい心が育つ過程を発達心理学者のエリクソン や橋本武夫は図1のように提唱している ${ }^{1), 2)}$.

抱いて・語りかけて・おつぱいでの母子相互作用 のなかで子の基本的信頼関係のおおもとは確立さ れ，母の母性は育まれていく，分娩は究極の育児の 原点といわれる所以である。

妊産婦にとり最も大切なことは妊娠中からそれら を知る機会, 学ぶ機会をもつことであり, 産科周産 期医療者はそれを提供する義務がある。

話は変わるが，山本一哉によると日本の名だたる 皮膚科医がお世話になったペンシルベニア大学の Albert M. Kligman, MD, Phd "Heald Skin is Not Heald” Skin “memory” may last a lifetime. ${ }^{3)}$ と述 べているという.

筆者は 15 年前に新生児, 乳幼児の皮膚の角質水 分量，皮表脂質量とも成人に比べて非常に少なく (半分以下), また角層機能も不十分なため乾燥しや すいことを知り ${ }^{4)}$ ，ただちに，これまで行ってきた
沐浴方法の見直しと適切なスキンケア，つまり“き 机いにそしてしっとり”を実施した。

乳幼児皮膚へのケアは，健常な皮膚を保ち，皮膚 疾患を予防し，アトピー性皮膚炎の素因をもつた乳 幼児でも掻かない状態を保つことができることを実 証し，その結果を 2002 年第 26 回日本小児皮膚科学 会において発表した ${ }^{5)}$.これらのサポートも健常児 とその母をサポートする産婦人科診療所だからこそ 簡単にできる役割の一つであると考えている.

以上のように日本独特と思われるわが国の産婦人 科診療所の果たすべき役割は，安全に分娩が終了す ることのみならず，母子の本来有している遺伝子が 成長過程のなかで見事開花するように，日本の社会 にほんの数十年前には当たり前に存在していた(今 は失われつつある? ) 環境を創り出し，母子が健や かに歪从なく成長していく過程を支えていくことに あると現時点では考えている。

\section{II 硬膜外麻酔分娩を始めた理由}

当院は 1960 年に開院，筆者が継承後の 1983 年 12 月に新築し分娩取扱いを再開した。

1986年 11 月, 島田信宏現北里大学名誉教授の周 


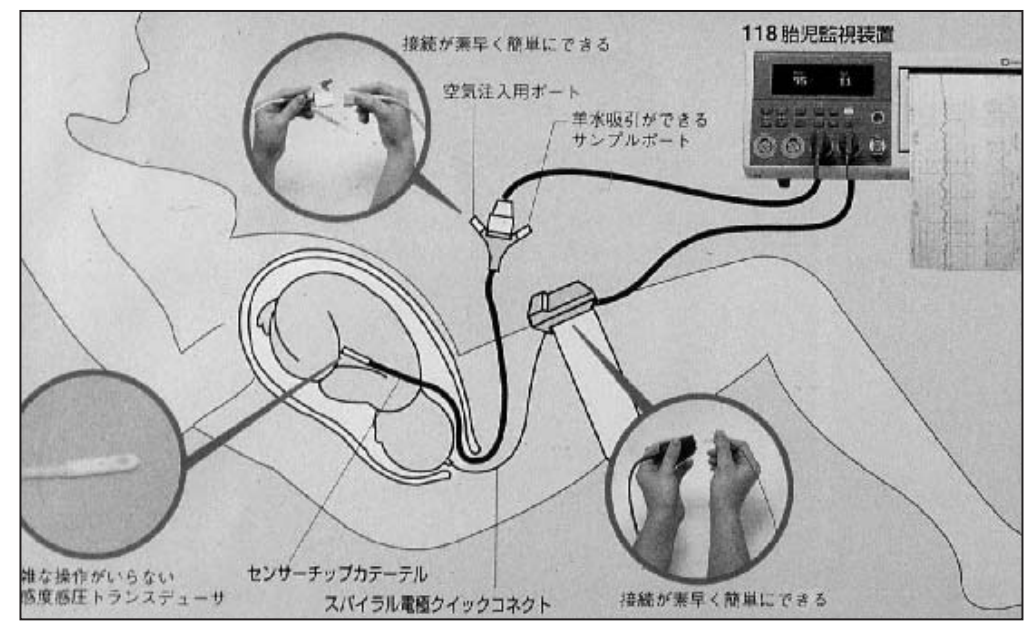

図2 子宮内圧測定法による分婏監視

産期セミナーで，センサーを子宮腔内に扱入して子 宮内压を直接測定する子宮収縮監視法＝直接法 $($ 日 本では内測法)の存在を知り, 以来今日まで 22 年間 ほとんどすべての分娩を内測法により監視し，それ に基づいて管理してきた。

内測法による子宮収縮曲線は腹壁より測定する外 側法に比し子宮収縮を他の因子に大きく影響される ことなく, 分娩進行のおのおのの時期の子宮収縮が その時期に応じて分娩を進行させるのに有効なもの であるか否かを表わしてくれる。

1997 年頃より新ラマーズ法, ソフロロジー法, ヨ ガ等の和痛法では対処しきれない不穏な不適切子宮 収縮による分娩(ほとんどは過強陣痛例，ハイパー トーヌス〈高子宮内基底圧〉)例を経験するようにな り, 分婏の安全な進行のためにそれらの症例に対し てやむを得ず硬膜外麻酔を使用した。硬膜外麻酔に より不穏な子宮収縮は解消され, 安全で有効な子宮 収縮が再現しスムーズな分娩進行がもたらされたの である。その年 (1997年)の硬膜外麻酔分娩率は $6 \%$ であるが翌年には 39\%と増加し，1999年には 87\%， 統計途中の 2007 年 8 月末の時点で $98 \%$ に達している. 2007 年 8 月 31 日までの全分娩数 6,900 例中, 帝王切 開も含めて 3,049 例の硬膜外麻酔分娩を経験した。

\section{1. 理想型分婏という考え方}

小林隆東京大学名誉教授は「分娩時間も非常に短 く, その出発点も途中経過も全くスムーズで, 産婦 もほとんど気にしないくらいの苦痛ですみ，新生児 も元気で, 後出血も少なく, 産後の回復も順調な分 娩」を理想型分娩と名づけた ${ }^{6}$. 産科周産期医療者 は取り扱うすべての分婏が理想型分娩でありたいと 憧れの気持ちをもって願っているはずである.

いわゆるよいお産とはこの理想型分娩であること に異論をはさむ者はいないであろう。

理想型分娩であるためには，分娩進行中の子宮収 縮が安全で有効であることが必須条件である。その ためには正しく適切な子宮収縮の評価，間欠期(子 宮収縮のない時期)の子宮内基底圧の評価を行う必 要がある。

この目的には子宮収縮を直接測定する監視方法 (内測法)が最も適している。

\section{2. 子宮内圧測定による子宮収縮の評価}

子宮内圧の測定は, 現在では先端にセンサーのつ いたカテーテルを子宮腔内羊水中に挿入し子宮内圧 を直接測定する方法で, 胎児心拍陣痛図 (CTG： cardiotocograph)に記録される(図2，図3).

CTGに記されている0/25/50/75/100の数字は, 


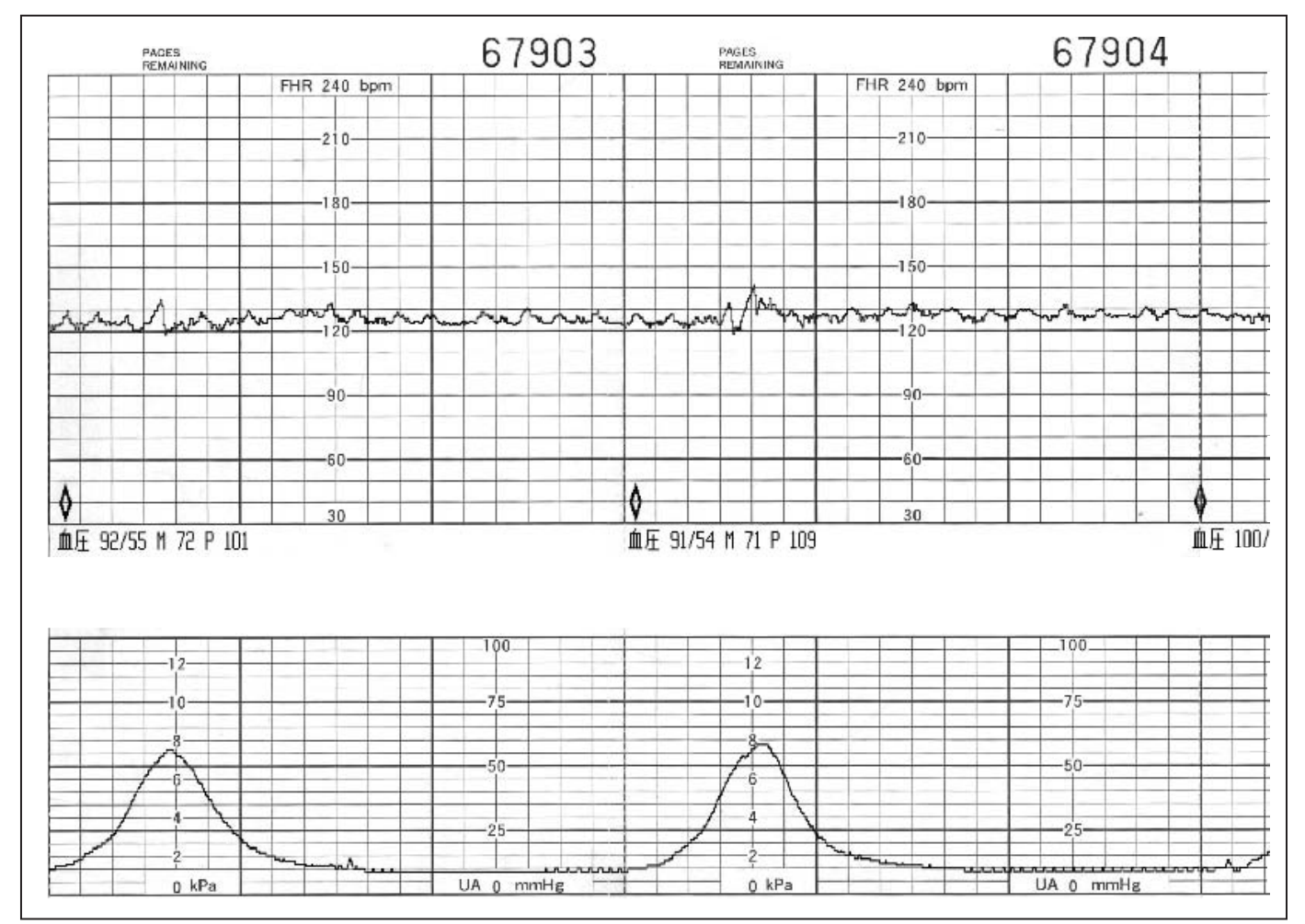

図3 子宮口開大 $8 \mathrm{~cm}$ のCTG

表1 安全に分婏が進行する子宮収縮

収縮回数：10 分間に3〜4回

収縮時間： $\quad 40 \sim 50$ 秒

子宮内压： $\quad 40 \sim 70 \mathrm{mmHg}$

子宮内基底圧：20mmHg 以下(理想は $10 \mathrm{mmHg}$ 以下)

内測法による測定值 $(\mathrm{mmHg})$ であり, 外側法 (腹 部にトランスデューサをつけて測定する方法)には 正しく相関しない，有効な子宮収縮は表 1 のとおり である。

人種年齢を問わず子宮内圧が $20 \mathrm{mmHg}$ を超えれ ば妊産婦は「お腹が張っている」と感じ， $25 \mathrm{mmHg}$ を超えれば「お腹が痛い」と感じる，40〜 $50 \mathrm{mmHg}$ を超えると分娩が進行する。 $75 \mathrm{mmHg}$ を超えると強 すぎる．分娩が進行するために有効な子宮収縮を有 効陣痛という。最近の子宮胎盤血流の研究によると 子宮胎盤灌流は子宮内圧が $30 \mathrm{mmHg}$ で 50 \% 減少し，
$40 \mathrm{mmHg}$ を超えると絨毛間灌流は途絶する ${ }^{7)}$ といわ れている。

\section{3. 硬膜外麻酔の効果}

筆者は 22 年間，このような子宮収縮のみで終了 するよう分娩の監視と管理を行ってきた． CTGの胎 児心拍数モニタリングは文字どおり子宮収縮と相関 して評価されるので，子宮収縮が正しく監視されて いない状況では胎児監視に影響を与える可能性が ある。

有効陣痛の域に達していない子宮収縮を微弱陣痛 というが，初産婦の $25 \mathrm{mmHg}$ 以下，経産婦の $19 \mathrm{mmHg}$ 以下の圧力では子宮口は開大しないという 報告もある ${ }^{8)}$.

先に不穏な陣痛と呼んだ子宮収縮は，表 2 のお りである。

最も注意すべきは基底圧の上昇したハイパートー ヌスと子宮内圧の上昇した過強陣痛であるが，これ 


\section{表2 不穏な子宮収縮}

\begin{tabular}{|c|c|c|}
\hline 収縮回数： & 10 分間に 6 回以上 & \\
\hline 収縮時間： & $60 \sim 90$ 秒以上 & 過強陣痛 \\
\hline 子宮内圧： & $75 \mathrm{mmHg}$ & \\
\hline
\end{tabular}

らは内測法でしか測定することができない.

これらの危険で分娩進行を妨げる子宮収縮の出現 する原因はさまざまな因子がかかわっていると考え られているが, 常位胎盤早期剥離や䋐毛膜羊膜炎等 の妊娠の異常による子宮胎盤血流の変化を除いた分 娩経過中に出現する原因の多くは, 妊産婦自身の分 娩に対する思いや諸々の原因による不安や恐怖など がもたらした過度のストレスが分娩メカニズムの自 律神経ホルモン系を乱し, さらにストレス状態を増 幅させ，ますます分娩を遷延させる悪循環スパイラ ルを生み出し, 順調な分娩進行とはかけ離れた異常 な分娩進行(難産)となってしまう。

分婏は病気ではないのだから何もしないのが一 番, 自然が一番よい, などと言って分婏開始より分 娩終了まで 3 日 3 晚かかりましたという話を今も聞 く。しかしそれは，何もせずにただじっと見ている だけの「放ったらかし分娩」であり，決して「自然 分婏」といえるものではなく, 母体と胎児の安全を 最大限の努力で守る産科周産期医療者の義務に反し ている.

不幸にしてこれらの状況に陥つても, 硬膜外麻酔 は $100 \%$ とはいえないにしてもきわめて有効で順調 な分娩進行をもたらせてくれる.

筆者は分娩進行を妨げるこれらの現象を 15 年位 前より経験するようになり，10年位前より顕著にな ってきたと感じている。

筆者が産婦人科医になった頃は分娩監視はトラウ べ主体であり, 出産直後に母子は分離され新生児室 に収容され，3時間ごとの授乳で退院時に出生体重 に戻すために人工乳も多く用いられ，家庭では子は ベビーベッドで寝かすことがよい子育てと考えられ
ていた. 加えて最近 10 年の社会環境の急激な変化, 特に利便性のあくなき追求等と何か関連があるので はないかと推測してみるが，当然それらを証明する ことはできない.これらの分娩現象の変化に気づい たのも， 22 年来，内測法による子宮収縮の監視を行 つてきた所以である。分婏を取り巻く最近の風潮に もよるのであろうが，その傾向はより顕著になって きている気がするが，硬膜外麻酔分娩はそれらの現 象を発生させることなく本来の分娩現象へ戻してく 机る。

以上のように，私達が硬膜外麻酔分娩を始めた理 由は，痛みもほとんどなく分娩もスムーズに進行し 後出血も少なく，産後もすぐに回復するようなお産 一理想型分婏を実現させるためである。長年子宮内 圧モニタリングを行ってきたゆえの帰結であり，産 婦の求めに応じてただ痛みを取るためだけに硬膜外 麻酔を使用してきたのでは決してない。さらに加え て母子ともに分婏による疲労が少ないため, 分婏直 後よりの母子同床を可能にし，おつぱい哺育への移 行を容易にもたらすのである.

\section{III 硬膜外麻酔分婏の実施にあたり留意している点}

次に硬膜外麻酔分婏を実施するにあたり留意して いる点をありのままに述べる.

\section{1. 妊婦に理解してもらうこと}

最初にそして最も大切なことは硬膜外麻酔分娩を 選択する妊婦にその目的と実際を理解し納得しても らい共感を得ることである，当院は当院の実状，妊 婦自身と胎児の安全のため何が必要かを理解しても らうために，十分なChild Birth Classを用意し，参 加するように働きかけを行っている.

\section{- 当院の実状}

産科麻酔専門医はいないこと，いつでも相談でき て指導してくれる麻酔専門医はいるが常勤の麻酔専 門医もいないこと，産婦人科専門医が麻酔を行って いること，したがってまずは安全第一を旨とし，期 待しているほど完全無痛ではないかもしれないこ 
と, スタッフも多くなく 24 時間同じ能力ではない こと, 常勤のスタッフは知識も技術も習熟し経験も 人間力も豊かであること等である.

・硬膜外麻酔分婏の目的

当院で実施している硬膜外麻酔分婏はあくまでよ いお産のため, 分娩が安全で有効な子宮収縮でスム ーズに進行するための分娩方法の一つであること等 である。

\section{2. 分婏準備状態の科学的診断}

医療技術の進歩は妊娠・分娩という妊娠していな い女性の生理的状態より逸脱した生理的状態 (病態 といっていい)に関しても多くの福音をもたらした. そのおかげで通常産婦人科医 1 人の開業医でも十分 妊産婦の役に立つことができているのであるが, 最 近の最大の福音は, 分娩準備状態が科学的に診断で きるようになったことである。

分娩が始まると産婦の子宮頸管内には破水時に検 出されるフリーのインスリン様成長因子結合蛋白質 1型, insulin-like growth factor-binding protein-1 (IGFBP-1) がリン酸化したIGFBP-1 抗体が増量す ることがわかってきた。

フィンランドの MEDIX BIOCHEMICA 社よりリ ン酸化された IGFBP-1 を検出する検査キットも発 売された (図4) $)^{9), 10)}$.

残念なことに日本で実用化するには至らなかった が, 当院ではフリーのIGFBP-1抗体を検出する破 水の診断薬のチェック $\mathrm{PROM}^{\circledR}$ (図5)を代用するこ とで分娩準備状態の診断法として十分に実用可能で 満足する結果を得ることができている.

通常, 妊娠 37 週以降の正期産の分娭準備状態は, 内診により行われてきた。 実際には子宮口の開大度, 熟化度, 先進児頭の位置, 胎児の成熟度, 胎位, 羊 水量, 母体合併症の有無などにより分娩準備状態を 診断し, 誘発促進分娩の適応であるかどうかを診断 してきたが, IGFBP-1抗体の診断を加えることで, その精度は格段に向上した。

これらの診断により誘発促進された分娩は, 産婦

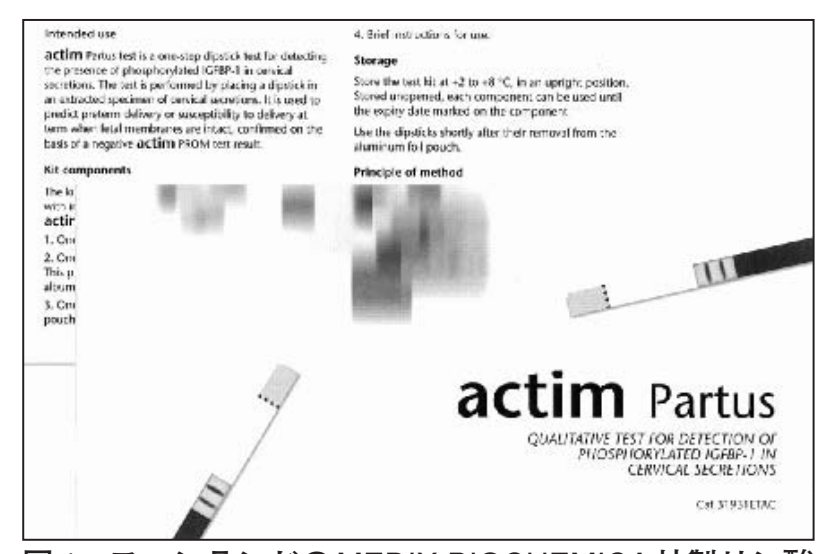

図4 フィンランドのMEDIX BIOCHEMICA 社製リン酸 化されたIGFBP-1を検出する検査キット

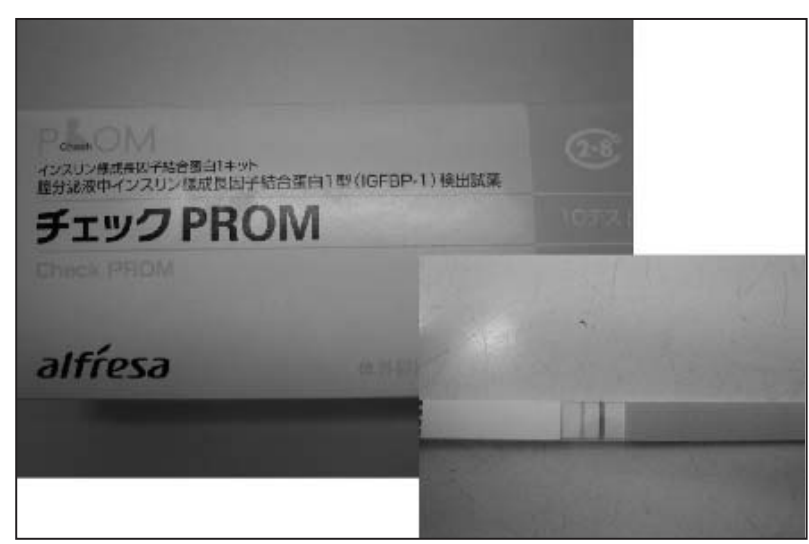

図 5 破水の診断検査キット「チェック $\mathrm{PROM}^{\circledR} 」$

自身のオキシトシン分泌とレセプター反応の同調 期＝活動期へ滞ることなく移行する症例がほとんど で分娩時間はさらに短くなった。またこのような誘 発促進分娩で他の分婏因子による分娩進行停止例を 除き, 分婏の遷延等の難産症例は経験していない. 余談であるが，いくら誘発促進しても，十分な内因 性ホルモン分泌なくして活動期へは移行しない. そ れこそ3日3晚かかっても終了しない分娩となって しまう。

それ以外の分娩準備状態の診断は, 妊婦が睡眠中 の午前 $2 \sim 4$ 時頃に $20 \sim 30$ 分ごとに繰り返される軽 い痛みを伴う子宮収縮を自覚した時の受診により行 われる。来院の目的は, 軽い痛みを伴う子宮収縮に 胎児が正常に耐えているかどうかを胎児心拍数モニ 
タリングで診断するためと母体の変調の有無の診断 のためである。この時にまず行う胎児心拍数モニ夕 リングと羊水量等の超音波診断は，これからの分娩 進行が安全であるかどうかを予測してくれる。この 胎児心拍数モニタリングのことを admission test (AT) という。ATが reassuringであれば，内診所見に IGFBP-1 抗体の測定を加えた分娩準備状態の診断 を行い, この分娩を誘発促進するか待機するかを診 断するが，その時間は通常の (当院の体制) 業務時間 の午前 7 時 30 分頃で十分である.

「陣痛が 10 分ごとになったら来院しなさい」等の 指導を行っていては, 安全で満足な分娩を創り出す ことは困難であるのみならず，それは母と子の生命 を必死に守るべき産科周産期医療者の姿勢ではな い. 開業産婦人科医は硬膜外麻酔分娩を行う場合の みならず，誘発促進分婏を行う場合，さらに何もす る必要のない分婏の場合でも, 科学的診断法を取り 入れた分娩準備状態の診断, 内測法による分婏の監 視と管理，母体の監視，を連続した母体胎児モニ夕 リングにより正確に行うべきであると考えている.

陣痛の苦痛を取るためのみに硬膜外麻酔を行い分 婏の監視と管理をおろそかにするようなことが決し てあってはならない。一部で硬膜外麻酔は分娩を遷 延させる, 鉗子分婏や吸引分娩が多くなる等々と言 われる最大の原因は，十分な分娭監視と管理が行わ れていたか否かにあると考えている。

\section{3. 分婏準備状態が診断された場合}

・妊産婦との間に同意された選択的誘発硬膜外麻酔 分婏の場合

分婏前日の夕方にミニメトロ(シリコン製の小さ なバルーンカテーテル)を内子宮口に挿入し $40 \mathrm{ml}$ の 生食を挿入する (図6). 扦入後 $2 \sim 3$ 時間に軽い子宮 収縮を認めることが多く, その時点で胎児心拍数モ ニタリング(AT)を行いこの分婏の経過中に胎児が 危険な事態にならないかどうかを評価する，翌朝， ミニメトロを抜去する(自然抜去している場合もあ る)。その時点でほとんどの症例は少なくとも子宮

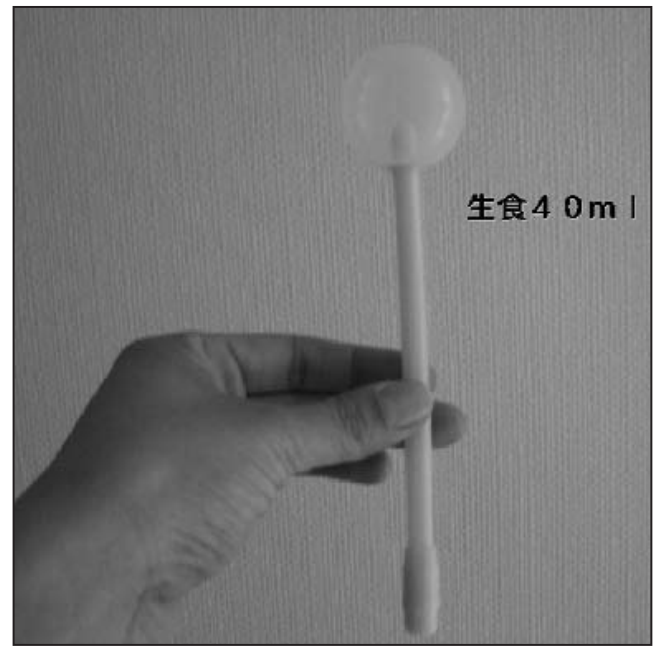

図6 ミニメトロ

口 $5 \mathrm{~cm}$ 以上 (多くは $6 \sim 7 \mathrm{~cm}$ ) 開大している。この状 態から硬膜外麻酔を行い, 内測法による分婏の監視 と管理を開始する。

・午前 $2 \sim 4$ 時に軽い陣痛を認めた場合

IGFBP-1 抗体の反応があり，子宮口 $3 \mathrm{~cm}$ 開大以 下であれば産婦の同意を得てミニメトロ挿入．2〜 3 時間後に $5 \mathrm{~cm}$ 以上の開大を確認し，ミニメトロ抜 去。硬膜外麻酔を行い，内測法による分娩の監視と 管理を開始する。

当院の場合，分娩の開始のほとんどは以上の 2 パ ターンである。

妊産婦がこれらの進歩した産科周産期医療を理解 し納得し, 私達と共感し合うことが, よりよいお産, よりよい硬膜外麻酔分婏を実現させるおおもとで ある。

何より大切なのは「教育」＝妊婦教育，そして職 員教育である。以下に妊婦と私達を支えてくれる指 導医を示す(敬称略).

- 島田信宏 (北里大学名誉教授 山王病院産婦人科) 平成 12 年 4 月 4 日〜 毎月 1 回 Child Birth class, 職員研修

- 橋本武夫 (久留米大学小児科臨床教授, 厚生労働 省健やか親子 21 委員）

平成 12 年 6 月 16 日〜 毎月 1 回 Child Birth 
class, 職員研修, 乳幼児健診

- 山本一哉(総合母子保健センター愛育病院皮膚科 部長)

平成 8 年 1 月 25 日〜 毎月 1 回 ミニセミナー, 小児皮膚科健診

・益子進也(長浜赤十字病院麻酔科部長) 平成 10 年〜 年 1 回 2 回 職員研修

\section{4. 硬膜外麻酔の実際}

・ LDR 室*に収容; 全身麻酔器, エフェドリン $1 \mathrm{~A}$, $5 \%$ グルース $20 \mathrm{~m} l$

*LDR (labor delivery recovery) 室：分婏の開始から 終了後数時間を過ごす部屋

・血管確保 ; $20 \mathrm{G}$ 静脈内留置針

- 麻酔前輸液 ; フィジオ ${ }^{\circledR} 140 \quad 500 \sim 1,000 \mathrm{~m} l$

・使用キット； アロー硬膜外麻酔用カテーテル キット

- 麻酔体位 ; 座位

・穿刺部位 ; L3/L4

硬膜外穿刺針を皮膚より $3 \mathrm{~cm}$ 弱挿入後, 触感法で 慎重に進め抵抗消失法にて確認。

カテーテルは片効き予防のため少し深目に挿入し 1〜2cm 引き約 $5 〜 6 \mathrm{~cm}$ で固定. 1\%キシロカイン $\mathrm{E}^{\circledR}$ (エピネフリン含有塩酸リドカイン) $1 \sim 2 \mathrm{ml}$ 注入. 5 分後に $0.1 \%$ アナペイン ${ }^{\circledR}$ (塩酸ロピバカイン) $5 \mathrm{ml}$ 注 入.その 5 分後に再度 $0.1 \%$ アナペイン ${ }^{\circledR} 5 \mathrm{~m} l$ を追加. 自覚症状とバイタルサインに異常のないことを確認 する。この状態で内診時の痛みはなくなっているの で, 人工破膜, 子宮内測カテーテルを挿入(このと き羊水の性状のチェックは非常に大切である. 現在 でも羊水の性状, 混濁の有無を人工破膜以前に診断 することはできない. また，臍帯の胎児への巻絡の 詳細を分娩前に診断することもできない. 残念なこ とである。これからの研究成果が待たれるところで ある)し, 児頭に胎児心拍数測定用の螺旋電極を装 着し, 分娩監視と管理を開始する.

その後, いかに早く無䭾なく有効陣痛を創り, 分 娩進行に適した子宮収縮で分娩を終了させるかが産
科医の仕事であり，言い換えれば腕の見せ所でも ある。

局所麻酔薬の追加は産婦の訴えにより行ってい る. 1 回目は $0.2 \%$ アナペイン ${ }^{\circledR} 5 \mathrm{~m} l, 2$ 回目以後は $0.2 \%$ アナペイン ${ }^{\circledR} 10 \mathrm{~m} l$ を追加している.

婏出直前 (排臨少し前)には軽い怒責を得るため投 与量を調節している.

当院はLDR室での分娩であるが，産婦は分娩後 の約 2 時間(新生児覚醒中の時間)をカンガルーケア で過ごした後, 自分の病室に帰ることを希望するの で，硬膜外カテーテルは帰室前に抜去している。

新生児は諸計測のあと全身の観察のため約 2 時間 を保育器で過ごし，母子同室(母子同床)が始まる。

\section{5. 帝王切開となった場合}

分娩中に帝王切開に変更となる場合もある。その 場合は硬膜外カテーテルはそのままで，0.75\%アナ ペイン®を産婦の身長に応じて $10 \sim 12 \mathrm{~m} l$ 追加する ことで血圧の低下もほとんどない安全で十分な麻醉 効果が得られている。

術後疼痛緩和にはクーデック®シリンジェクター® ${ }^{\circledR}$ に $0.2 \%$ アナペイン ${ }^{\circledR} 50 \mathrm{~m} l+$ フェタニル ${ }^{\circledR}$ (フェンタ ニルクエン酸塩) $0.1 \mathrm{mg} 2 \mathrm{ml}$ を混注し使用している.

ちなみに分娩中に帝王切開へ変更となる理由のほ とんどは分娩前には診断できない児頭の骨産道への 不正軸進入や複雑な臍帯巻絡等であり，いずれも有 効陣痛があるにもかかわらず，進行が遅い遷延例や 進行しない停止例である。ちなみに有効陣痛を評価 することなく分婏の遷延や停止を診断することはで きない，当院のその頻度は，硬膜外麻酔分婏を実施 していなかった時代と同率で約 $3 \%$ あ゙る. 硬膜外 麻酔分娩の何よりありがたいところは，帝王切開と 決定してから胎児娩出までの時間が大幅に短縮でき ることで, 最短は 13 分であったがそれほど緊急な 症例はめつたに経験しない. 硬膜外麻酔分娩はいわ ゆる自然分娩での難産の発生を大幅に減少させるこ とを経験し，難産になりそうな症例や難産になって しまった症例にはぜひ硬膜外麻酔分婏を試みるべき 


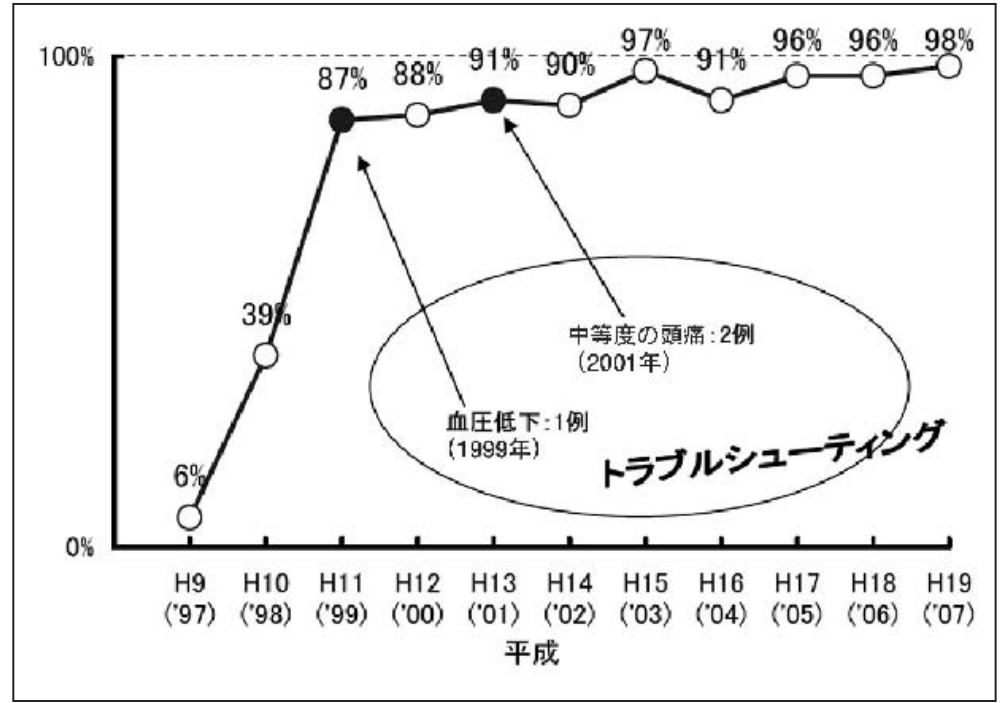

図7 硬膜外麻酔分婏の推移とトラブルシューティング

と考えている.

6. 硬膜外麻酔分婏の推移とトラブルシューティング

硬膜外麻酔分娩率の推移を図 7 に示す。1997年, やむを得ず導入を始めた年は 6\%，1998年 39\%，

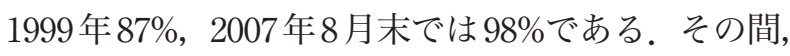
トラブルシューティングは 3 例経験した。1999年， テストドーズ(当時は $0.25 \%$ マーカイン ${ }^{\circledR}$ 塩酸ブピ バカイン〉)を注入後数分で収縮期血圧 $60 \mathrm{mmHg}$ 以 下の血圧低下をきたし, エフェドリンにて回復, 分 婏は無事終了したが，回復直後に抜去したカテーテ ルに血液の付着を認めた症例および，2001年，分婏 後に中等度の頭痛を 6 日間認めた 2 例である.

その後は幸いなことにトラブルシューティングの 経験はない.

\section{7. 分婏開始時間}

当院の 2005 年より 3 年間の分娩開始時間を図 8 に 示す。ほとんどの分娩は午前 10 時前後に始まって いる.

\section{8. 分婏所要時間}

当院の 2005 年より 3 年間の分娩時間を表 3 に示す. 初産婦は平均 5 時間 48 分, 経産婦は平均 3 時間 17 分である。つまりほとんどの分娩は午前 10 時頃に
始まり，経産婦は午後 1 時頃に，初産婦は午後 4 時 頃までに終了している.

\section{9. 硬膜外麻酔分婏率}

2007 年 7 月米国ワシントン州シアトルの Swedish Medical Centerを見学する機会があった。

Swedish Medical Centerの分婏はすべてBirthing Suite と呼ばれるLDR室で行われている。年間分娩 数は約 8,000 例, 硬膜外麻酔分娩率は $85 \%$ であった。 硬膜外麻酔分娩が行われない $15 \%$ のとんどが分婏 徵候を認めてBirthing Suiteの triageを受診したと きにはすでに硬膜外麻酔施行が間に合わなかった症 例で，ごく一部に硬膜外麻酔を希望しない妊婦がい るとのことであった。ちなみに内測法による分娩監 視を希望しない妊婦も存在するという。個人の考え 方や慣習が原因であると聞かされた(その場合，初 産婦の平均分婏時間は 12 時間とのことである).

産婦は分娩後 36 時間で退院する。その間をLDR 室で過ごすため，LDR室はとても豪華であった。ち なみに帝王切開を行った場合は 3 日で退院である.

京都市では 2006 年の出生数は 11,845 例，その分婏 を病院 20 , 診療所 19 , 助産院 6 で行っている，当院 以外にここで述べた内容の硬膜外麻酔分娩を行って 


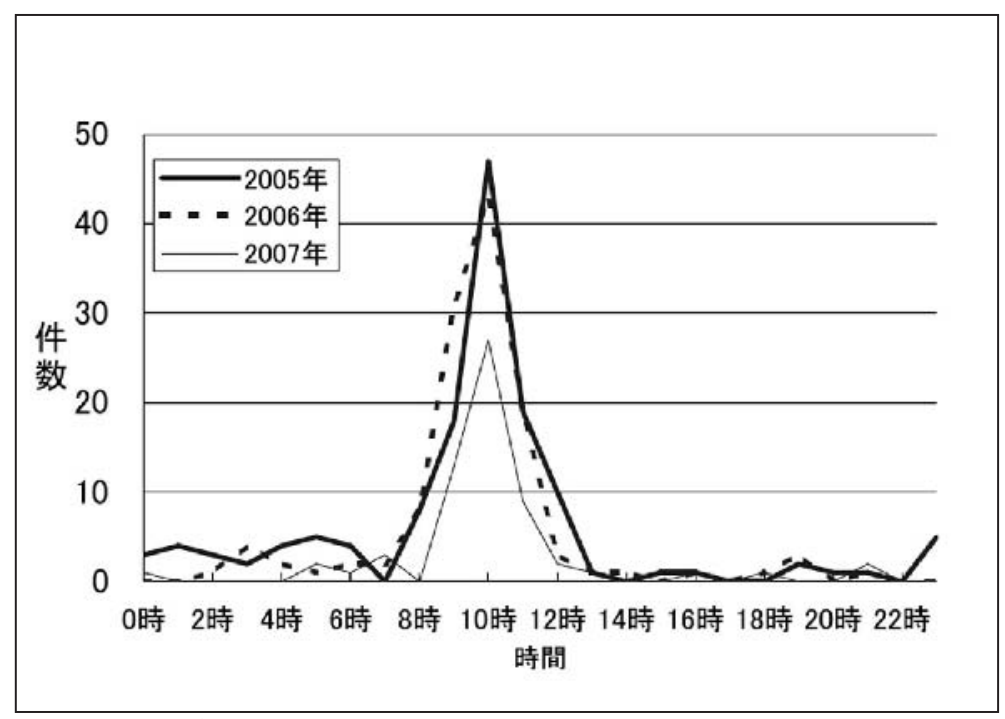

図8 最近3年間の分婏開始時間

表 3 最近 3 年間の分婏 I 期, 分婏 II 期, 分婏時間の平 均時間

\begin{tabular}{lccc}
\hline & 分婏 I 期 & 分婏 II 期 & 分婏時間 \\
\hline 初産婦 $(n=147)$ & $4: 04$ & $2: 13$ & $5: 48$ \\
経産婦 $(n=178)$ & $2: 20$ & $1: 38$ & $3: 17$ \\
\hline & & $(2005$ 年, 2006 年, 2007 年 $)$
\end{tabular}

いる施設はないようなので, 硬膜外麻酔分婏率は $1.6 \%$ ということになる。

\section{おわりに，そして期待すること， できることなら}

38 年間分婏の現場に立ち会い, ヒトの生命と心の 原点を守る仕事をさせていただいた。最近 10 年は 試行錯誤しながら硬膜外麻酔分婏を約 3,000 例取り 扱ってきた。その結果，硬膜外麻酔分娩がよりよい お産＝理想型分娩を創出するのにいかに有用である かの確信をもてるようになった。 さらに出生後 2 年 間あまり，看続けさせてもらった母と子が幼児，児 童となって訪ねてくれた姿から学んだ事実がある. それは硬膜外麻酔分娩が，母の母性の確立の原点， 子の基本的信頼関係確立の原点, 究極の育児の原点 を歪みなく健やかに創出してくれるということである.
通常，産科医 1 人と少数のスタッフの産科開業医 にとり，妊婦とともに安全・安心かつ快適で納得で きる分婏を創出するため硬膜外麻酔分娩は最適の分 娩法の一つである。しかしながら分婏の監視と管理 は母体と胎児の生命を見つめることである。したが ってそこで行われる硬膜外麻酔は産科麻酔医により 行われることが最良であり，それが無理としても麻 酔専門医により行われるべきであることに論を待た ない.

当院には幸いどんな時間帯でも相談し指示をいた だける麻酔専門医がいてくれているが，何か有事の ときの不安が消えることはない，麻酔科医の不足が 産科医不足と変わることなく報道されている現在, 今寸ぐにこの夢がかなうことは不可能であろうが, 近い将来, 産科周産期医療現場に麻酔専門医が立ち 会っていただけることを心より期待し待望するのは, 産科周産期医療に携わる者すべての思いであろう。

産科周産期の分野においても科学的診断は確実に 進歩し，妊婦診察をしつかり行うことで通常の分婏 は時間的にそれほどの負担をかけることなく管理で きる時代になっているので, 麻酔専門医の先生方に 重いご負担をおかけすることはないと思われる。麻 
酔専門医の先生方にぜひ硬膜外麻酔分婏へ目を向け ていただき，よりよいお産のためへのお力添えを心 よりお願い申し上げる次第である.

以上，一産婦人科開業医がよりよいお産，よりよ い分婏監視と管理のためにと 10 年間, 約 3,000 例の 硬膜外麻酔分娩に付き添ってきたありのままを述べ させていただいた。

謝辞 稿を終えるにあたつて発表の機会を与えてい ただいた日本臨床麻酔学会第 27 回大会会長 小川節 郎先生, 座長 奥富俊之先生, コメンテー夕 島田洋 一先生に対して，この場をお借りして深甚なる謝意 を表します(本稿の要旨は, 日本臨床麻酔学会第 27 回大会で発表した)。

\section{おわび 硬膜外麻酔分婏の硬膜外麻酔の手技等につ} いてょり，筆者の分娩への想いを述べることに重き がおかれてしまいました。硬膜外麻酔が有効な子宮 収縮のみで分娩が終了する本来あるべき自然分婏を 創出し, 究極の育児の原点, 母性の原点を特に意識 することなく健やかに楽しく創出してくれることを 確信するに至ったがゆえの一産婦人科開業医の想い とお許しいただきますようお願い申し上げます。

追記 発表のあと, 多くの麻酔科の先生方より帝王 切開の局所麻酔薬の量は $0.75 \%$ アナペイン ${ }^{\circledR} 10$ $12 \mathrm{ml}$ より $0.375 \%$ アナペイン ${ }^{\circledR} 20 \mathrm{ml}$ が敃针めであると のご指摘をいただいた。早速変更してみると, 麻酔 効果は十分で下肢の筋弛緩が大幅に減弱され, 産婦 は大きな驚きと満足を抱いてくれた。特に反復帝王 切開の産婦には感動されるほどであった。それなら
ばと硬膜外麻酔分婏の追加局所麻酔薬の $0.2 \%$ アナペ

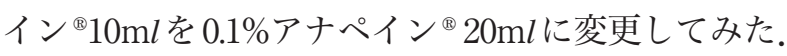
2007 年 11 月， 12 月の硬膜外麻酔分娩 15 例中 8 例が 十分有効であり，7例は $0.2 \%$ アナペイン®を必要と

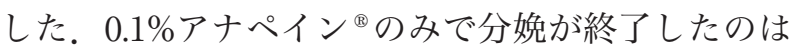
約半数であった。ただ全例で子宮口全開大後の怒責 のためには $0.1 \%$ アナペイン ${ }^{\circledR} 20 \mathrm{ml}$ が有効であるとの 感触を得た。ご指導いただいた先生方に感謝申し上 げる。

\section{参考文献}

1）橋本武夫ほか：平成 19 年度「家族・地域のきずなを再 生する国民運動」啓発パンフレット。「家族・地域のき ずな」フォーラム実行委員会・内閣府. 内閣府政策統括 官, 2007, 7

2）庄司順一：ライフステージと心の発達. 母子保健情報 第54号：19-23，2006. 11

3) Kligman AM : The invisible dermatoses. Arch Dermatol 127 : 1375-1382, 1991

4）山本一哉, 川尻康晴, 須山茂子ほか: 乳幼児の皮膚生 理特性(第 1 報)。日小皮誌 $12: 77-81,1993$

5）島岡昌幸：新しい産科指導から。 日小皮誌 $21 ： 94-98$, 2002

6）島田信宏：社会医学的選択的誘発分婏，周産期の母児 管理(改訂 5版)。南山堂，東京，2003，392

7）Sanjay Datta著，奥富俊之訳 : 子宮胎盤血流，最新産科 麻酔ハンドブック。メジカルビュー社, 東京, 2007, 51

8）高橋通，菊池三郎 : 子宮収縮の評価，最新の周産期管 理。武田佳彦監。医科学出版社, 東京, 1994, 123

9）島田信宏, 谷昭博, 島岡昌幸ほか：妊娠末期における 子宮頸管からのリン酸化 IGFBP-1 (インスリン様成長因 子結合蛋白質 1 型) の検出. 周産期医学 $35: 869-874$, 2005

10）島田信宏，エバ・マリア・ルタネン：PROMニュース vol. 1.2003 


\title{
Points of Concern for the Epidural Birth from the Perspective of Private Practice
}

\author{
Masayuki SHIMAOKA \\ Shimaoka Clinic
}

Over the past 10 years, I have experienced approximately 3,000 epidural births.

Obstetricians strive for ideal childbirth in all deliveries that they undertake, namely an extremely short delivery time, a smooth delivery from start to finish, minimal discomfort for the laboring mother, a healthy newborn, minimal postpartum bleeding, and a quick recovery after delivery.

As an obstetrician in private practice for 22 years using internal direct monitoring for delivery, I have arrived at the conclusion that the epidural birth is extremely effective in achieving an ideal delivery. I have been able to achieve a sympathetic agreement with the mother, whereby the pregnancy is safe, peaceful, and pleasant, and the mother says to me "If this is what delivery is all about, then I will come here to deliver again!"

The epidural birth is effective in keeping healthy, not distorting, the extreme beginning of childrearing.

Below, I state my points of caution as a private-practice obstetrician whose medical practice lacks significant manpower.

Key Words : Epidural birth, Painless childbirth, Delivery management, Elective-induction epidural birth, $\mathrm{Re}^{-}$-creation of the ideal childbirth

The Journal of Japan Society for Clinical Anesthesia Vol.28 No.5, 2008 